\title{
In silico Pulsed Field Gel Electrophoresis and Molecular characterization of Escherichia coli
}

\author{
Nusrat Nahar, Samia Naz, Sharmeen Asad, Md. Shariful Islam, D. A. Anwar Al Aman, Nurul Islam Setu, Tufael Ahmed, \\ Md. Kamrul Islam, Muhammed Mahfuzur Rahman, Md. Abdul Bari, Ridwan Bin Rashid* \\ Computational Chemistry and Bioinformatics Laboratory, Department of Pharmacy, State University of Bangladesh, Dhaka.
}

\section{ARTICLE INFO}

Article history:

Received on: 17/04/2017

Accepted on: 28/06/2017

Available online: $30 / 11 / 2017$

Key words:

Adhesin genes, Antibiotic

resistance genes, Escherichia

coli, Genotyping, PCR,

PFGE, Virulence genes.

\begin{abstract}
Sixty-five isolates were analyzed for virulence, antibiotic resistance and adherence genes by in silico tools. Thirteen virulence genes were selected to classify Escherichia coli isolates. The most prevalent virulence gene was shiga toxin, stx2 (13.85\%). Out of the 65 isolates, 3 isolates were harbouring heat labile enterotoxin (LT1) and isolate NC_017633 Escherichia coli ETEC H10407 and NC_017641 Escherichia coli UMNK 88 harboured STI and STII genes, respectively, both of which were representative of ETEC. Six isolates were positive for $v t 1$; and none of the isolates had the $v t 2$ gene. The intimin gene, eaeA was detected in seven isolates (10.77\%). The presence of Escherichia coli $\mathrm{O} 157$ was confirmed by $r f b E$ genes that were present in five isolates (7.69\%). Among the $8 h l y A$ positive isolates, 5 were positive for both $h l y A$ and $e a e A$ genes that classified the isolates into typical EHEC. Two isolates (NC_013941 Escherichia coli O55:H7 str. CB9615 and NC_017656 Escherichia coli $\mathrm{O} 55: \mathrm{H} 7$ str. RM12579) were classified as atypical EPEC as contained only eaeA gene and no bfpA gene. Five isolates $(7.69 \%)$ were positive for astA gene and four isolates $(6.15 \%)$ had the $a g g R$ gene. So most prevalent verotype was EHEC (11 isolates), followed by ETEC. No Enteroinvasive E. coli (EIEC) was found. Eleven isolates (16.92\%) had the sulfonamide resistance gene, sul2. The curli genes, $c s g A$ and $c r l$ were seen in $31(47.69 \%)$ and 40 isolates $(61.54 \%)$, respectively. Eleven isolates $(16.92 \%)$ had the type 1 fimbriae and these isolates were likely to form biofilm on abiotic surfaces. The $s f a$ gene was detected in 5 isolates and hence these isolates might be able to bind to receptors containing sialic acid residues. None of the isolates had the genes papC which are required for colonization on uroepithelial cells. In silico pulsed-field gel electrophoresis (PFGE) was able to group isolates into 25 genotypes. Genotype 8 was more virulent and contained only EHEC isolates. Genotype 17 contained all antibiotic resistance genes except tetC, sul3 and catAl genes. Genotype 17 also contained three adhesive genes. Virulence profile analyzed in this study helps to compare the genes with previously published human pathogenic strains and verify possible genetic similarities and assess the distribution of these genes based on genotypes. This study helps to select antibiotic for treatment and improve the outcomes with severe bacterial infections based on genotyping.
\end{abstract}

\section{INTRODUCTION}

People in the developing countries suffer from diarrheal disease because of unsafe drinking water, poor sanitation and hygiene practice. Virulence property of Escherichia coli may

\footnotetext{
* Corresponding Author

Ridwan Bin Rashid, Computational Chemistry and Bioinformatics Laboratory, Department of Pharmacy, State University of Bangladesh, Dhaka.Email: ridwan@sub.edu.bd
}

contribute to life-threatening diseases in humans. Heat labile (LT) and heat stable (ST) enterotoxins disrupt the balance of intestinal fluid and cause hypersecretion of fluid and electrolytes (Hughs et al., 1978; Moon 1978). Shiga toxin producing E. coli (STEC) produced two toxins (Stx1 and Stx2) which were reported earlier by Jafari et al. (2012). Enterohemorrhagic E coli (EHEC) strain causing hemorrhagic colitis (HC) was reported by Nataro and Kaper (1998). Aldick et al. (2007) published that EHEC hemolysin, ehx is cytotoxic to endothelial cells and contribute to the development of HUS (Hemolytic uremic syndrome). 
A new strain named Entero-Aggregative Haemorrhagic E. coli (EAHEC) was identified by $\mathrm{Wu}$ et al. (2011) and Brzuszkiewicz et al. (2011) that had the virulence property of EAEC and produced stx 2 but had no LEE pathogenic property. As previously described by Croxen and Finlay (2010) and Johnson and Nolkan (2009), EHEC contains enterocyte effacement locus (LEE) like EPEC and produces attaching and effacing lesions (A/E). Vila et al. (1998) demonstrated that EAST-1 is a heat stable enterotoxin encoded by many other pathogens besides EAEC. Mulvey et al. (1998) described that UPEC strain is responsible for UTI (Urinary tract infection) infection with the expression of broad-spectrum virulence factors. Adhesin gene helps them to colonize not only to cells but also help them to form biofilms. He et al. (2012) reported that biofilms might enhance their resistance to environmental perturbations and help them to survive in harsh conditions. Lopez-Banada et al. (2014) described that papC gene is responsible for pyelonephritis. Other fimbriae that are associated with adherence are type 1 fimbriae (fimA), S fimbriae ( $f f a$ ), curli fimbriae (csg) etc. (Mulvey, 2002; Antao et al., 2009; Johnson and Stell, 2000). Anonymous (2004), Danmap (2004), Guerra et al. (2003) and Lanz et al. (2003) reported that E. coli is mostly resistant to tetracyclines, sulfonamides, streptomycin or spectinomycin. Continuous evaluation of antibiotic resistance gene prevents the emergence of multidrug-resistant strains.

These data help to predict virulence, antibiotic resistance and adhesion genes of $65 \mathrm{E}$. coli isolates and identifies genes responsible for $E$. coli infections. Identification of antibiotic resistance genes also help to select effective antibiotic against $E$. coli infections.

\section{MATERIALS AND METHODS}

\section{Strains used}

Isolates used in this study are summarized in Table 1.

Table 1: Name of the isolates.

\begin{tabular}{|c|c|}
\hline $\begin{array}{c}\text { Serial } \\
\text { number }\end{array}$ & Isolate name \\
\hline 1 & NC_017910 Escherichia blattae DSM 4481 \\
\hline 2 & NC_011601 Escherichia coli 0127:H6 E2348/69 \\
\hline 3 & NC_017626 Escherichia coli 042 \\
\hline 4 & NC_008253 Escherichia coli 536 \\
\hline 5 & NC_011748 Escherichia coli 55989 \\
\hline 6 & NC_017631 Escherichia coli ABU 83972 \\
\hline 7 & NC_008563 Escherichia coli APEC O1 \\
\hline 8 & NC_020163 Escherichia coli APEC O78 \\
\hline 9 & NC_010468 Escherichia coli ATCC 8739 \\
\hline 10 & NC_012967 Escherichia coli B str. REL606 \\
\hline 11 & NC_012892 Escherichia coli BL21(DE3) \\
\hline 12 & NC_012971 Escherichia coli BL21(DE3) \\
\hline 13 & NC_012947 Escherichia coli BL21-Gold(DE3) pLysS AG \\
\hline 14 & NC_012759 Escherichia coli BW2952 \\
\hline 15 & NC_004431 Escherichia coli CFT073 \\
\hline 16 & NC_017638 Escherichia coli DH1 \\
\hline 17 & NC_017625 Escherichia coli DH1 \\
\hline 18 & NC_009801 Escherichia coli E24377A \\
\hline 19 & NC_011745 Escherichia coli ED1a \\
\hline
\end{tabular}

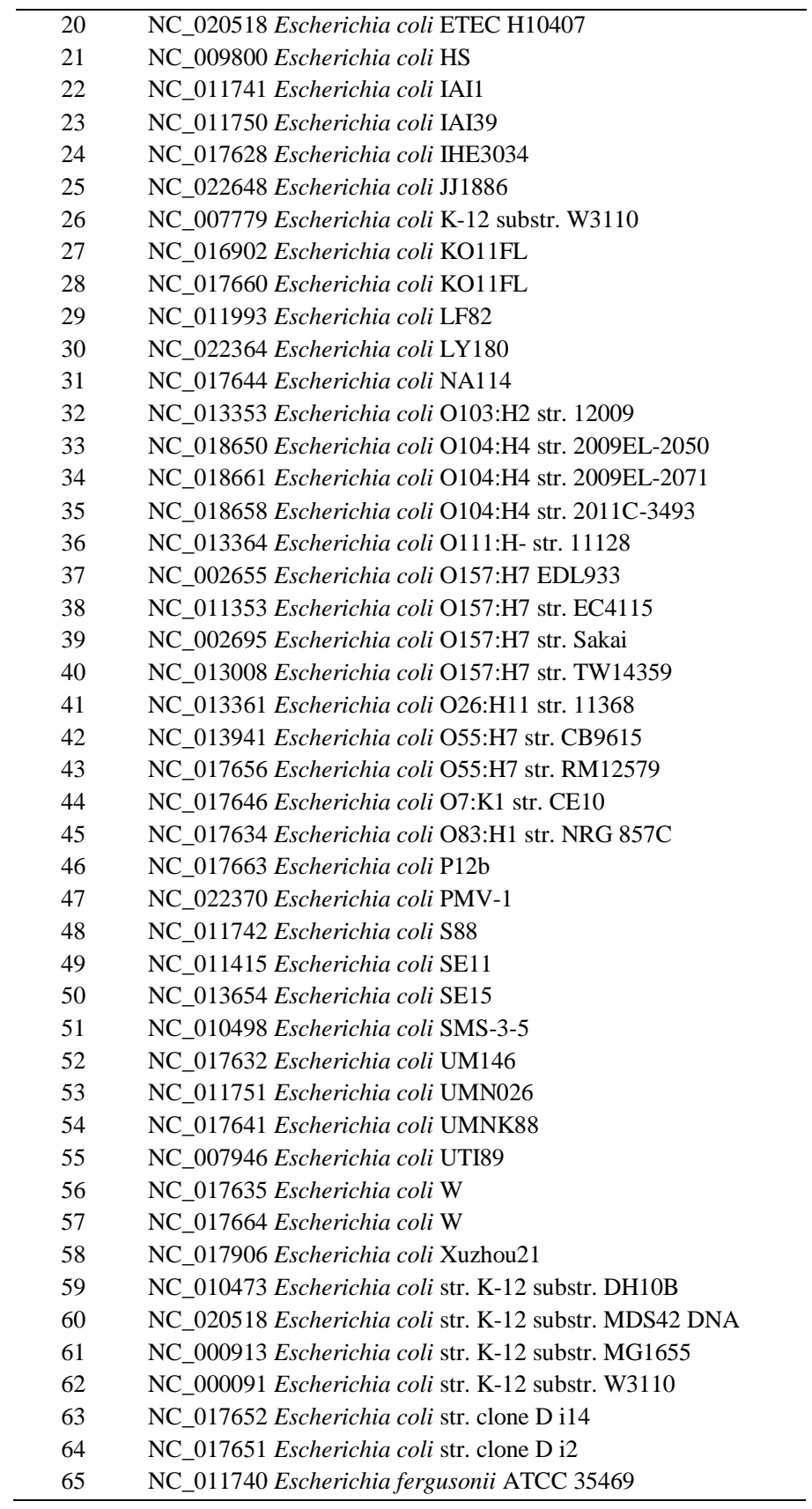

\section{PCR primers}

The primers used in the study are summarized in the Tables 2, 3 and 4 .

\section{PCR amplification}

An online basis software, http://insilico.ehu.eus/PCR/ was designed to perform in silico PCR amplification and endonuclease digestion (San Millan et al., 2013; Bikandi et al., 2004). PCR amplification was performed by selection of genome and introduction of a primer; and resulting PCR product is computed automatically with desired band size of a specific gene (Bikandi et al., 2004). 
Table 2: Primers used for virulence gene detection.

\begin{tabular}{|c|c|c|c|c|}
\hline Virulence factor & Gene & Primer Sequence (5' to 3') & Amplicon size (bp) & Reference \\
\hline Verotoxin 1 & $v t 1$ & $\begin{array}{l}\text { GAA GAG TCC GTG GGA TTA CG } \\
\text { AGC GAT GCA GCT ATT AAT AA }\end{array}$ & 130 & Pollard et al.,1990 \\
\hline Verotoxin 2 & $v t 2$ & $\begin{array}{l}\text { ACC GTT TTT CAG ATT TTGACA CAT A } \\
\text { TAC ACA GGA GCA GTT TCA GAC AGT }\end{array}$ & 298 & Pollard et al., 1990 \\
\hline Intimin & $e a e A$ & $\begin{array}{l}\text { CAC ACG AAT AAA CTG ACT AA AAT G } \\
\text { AAA AAC GCT GAC CCG CAC CTA AAT- }\end{array}$ & 376 & Pollard et al.,1990 \\
\hline Heat labile toxin 1 & LT1 & $\begin{array}{l}\text { TGGATTCATCATGCACCACAAGG } \\
\text { CCATTTCTCTTTTGCCTGCCATC }\end{array}$ & 360 & Pass et al., 2000 \\
\hline Heat stable toxin 1 & STI & $\begin{array}{l}\text { TTTCCCCTCTTTTAGTCAGTCAACTG } \\
\text { GGCAGGATTACAACAAAGTTCACAG }\end{array}$ & 160 & Pass et al., 2000 \\
\hline Heat stable toxin 2 & STII & $\begin{array}{l}\text { CCCCCTCTCTTTTGCACTTCTTTCC } \\
\text { TGCTCCAGCAGTACCATCTCTAACCC }\end{array}$ & 423 & Pass et al., 2000 \\
\hline $\begin{array}{l}\text { Cytotoxic necrotizing factor } \\
1\end{array}$ & cnfl & $\begin{array}{l}\text { GGCGACAAATGCAGTATTGCTTGG } \\
\text { GACGTTGGTTGCGGTAATTTTGGG }\end{array}$ & 552 & Pass et al., 2000 \\
\hline $\begin{array}{l}\text { Cytotoxic necrotizing factor } \\
2\end{array}$ & cnf2 & $\begin{array}{l}\text { GTGAGGCTCAACGAGATTATGCACTG } \\
\text { CCACGCTTCTTCTTCAGTTGTTCCTC }\end{array}$ & 839 & Pass et al., 2000 \\
\hline Hemolysin A & hlyA & $\begin{array}{l}\text { AGCTGCAAGTGCGGGTCTG } \\
\text { TACGGGTTATGCCTGCAAGTTCAC }\end{array}$ & 569 & Wang et al., 2002 \\
\hline Perosaminesynthetase & $r f b E$ & $\begin{array}{l}\text { CTACAGGTGAAGGTGGAATGG } \\
\text { ATTCCTCTCTTTCСTCTGCGG }\end{array}$ & 327 & Wang et al., 2002 \\
\hline Invasion Plasmid Antigen & ipaH & $\begin{array}{l}\text { TGG AAA AAC TCA GTG CCT CT } \\
\text { CCA GTC CGT AAA TTC ATT CT }\end{array}$ & 422 & Luscher et al.,1994 \\
\hline $\begin{array}{l}\text { Enteroaggregative } \\
\text { heat-stable enterotoxin }\end{array}$ & astA & $\begin{array}{l}\text { CCA TCA ACA CAG TAT ATC CGA } \\
\text { GGT CGC GAG TGA CGG CTT TGT }\end{array}$ & 111 & $\begin{array}{l}\text { Yamamoto and Nakazawa, } \\
1997\end{array}$ \\
\hline Bundle forming pilus & bfpA & $\begin{array}{l}\text { GCCGCTTTATCCAACCTGGTA } \\
\text { GCTGGAAAAACTCAGTGCCT }\end{array}$ & 326 & Sohelet at., 1993 \\
\hline Transcriptional activator & $\operatorname{aggR}$ & $\begin{array}{l}\text { GTATACACAAAAGAAGGAAGC } \\
\text { ACAGAATCGTCAGCATCAGC }\end{array}$ & 254 & $\begin{array}{l}\text { Ratchtrachenchai } \\
\text { et al., } 1997\end{array}$ \\
\hline Shiga toxin 1 & stx1 & $\begin{array}{l}\text { CGC TGA ATG TCA TTC GCT CTG C } \\
\text { CGT GGT ATA GCT ACT GTC ACC }\end{array}$ & 302 & Blanco et al., 2004 \\
\hline Shiga toxin 2 & stx 2 & $\begin{array}{l}\text { CTT CGG TAT CCT ATT CCC GG } \\
\text { CTG CTG TGA CAG TGA CAA AAC GC }\end{array}$ & 516 & Blanco et al., 2004 \\
\hline
\end{tabular}

Table 3: Primers used for adhesin gene detection.

\begin{tabular}{|c|c|c|c|c|}
\hline Adhesin gene & Gene & Primer Sequence (5' to 3') & Amplicon size (bp) & Reference \\
\hline Type1 fimbriae & $\operatorname{fimA}$ & $\begin{array}{l}\text { CGA CGC ATC TTC CTC ATT CTT CT } \\
\text { ATT GGT TCC GTT ATT CAG GGT TG }\end{array}$ & 721 & $\begin{array}{l}\text { Nowrouzian et al., } \\
2001 \text {. }\end{array}$ \\
\hline S fimbrial adhesion & $s f a$ & $\begin{array}{l}\text { CTC CGG AGA ACT GGG TGC ATC TTA C } \\
\text { CGG AGG AGT AAT TAC AAA CCT GGC A }\end{array}$ & 410 & $\begin{array}{l}\text { Le Bouguenec et al., } \\
1992\end{array}$ \\
\hline Curlin Subunit Gene & $\operatorname{csg} A$ & $\begin{array}{l}\text { ACT CTG ACT TGA CTA TTA CC } \\
\text { AGA TGC AGT CTG GTC AAC }\end{array}$ & 200 & Maurer et al., 1998 \\
\hline Curli Regulatory Gene & $c r l$ & $\begin{array}{l}\text { TTT CGA TTG TCT GGC TGT AT } \\
\text { CTT CAG ATT CAG CGT CG TC }\end{array}$ & 250 & Maurer et al., 1998 \\
\hline $\begin{array}{l}\text { Pyelonephritis } \\
\text { associated pili C }\end{array}$ & papC & $\begin{array}{l}\text { GAC GGC TGT ACT GCA GGG TGT GGC G } \\
\text { ATA TCC TTT CTG CAG GGA TGC AAT A }\end{array}$ & 328 & $\begin{array}{l}\text { Le Bouguenec et al., } \\
1992\end{array}$ \\
\hline
\end{tabular}

Table 4: Primers used for antibiotic resistance gene detection.

\begin{tabular}{|c|c|c|c|c|}
\hline Antibiotic resistance gene & Gene & Primer Sequence (5' to 3') & Amplicon size (bp) & Reference \\
\hline $\begin{array}{l}\text { Streptomycin } \\
\text { gene }\end{array}$ & $s t r B$ & $\begin{array}{l}\text { ATCGTCAAGGGATTGAAACC } \\
\text { GGATCGTAGAACATATTGGC }\end{array}$ & 509 & $\begin{array}{l}\text { Madsen et al., } \\
2000\end{array}$ \\
\hline $\begin{array}{l}\text { Tetracycline } \\
\text { gene }\end{array}$ & tetA & $\begin{array}{l}\text { GGCGGTCTTCTTCATCATGC } \\
\text { CGGCAGGCAGAGCAAGTAGA }\end{array}$ & 502 & Lanz et al., 2003 \\
\hline $\begin{array}{l}\text { Tetracycline } \\
\text { gene }\end{array}$ & tetB & $\begin{array}{l}\text { CATTAATAGGCGCATCGCTG } \\
\text { TGAAGGTCATCGATAGCAGG }\end{array}$ & 930 & Lanz et al., 2003 \\
\hline $\begin{array}{l}\text { Tetracycline } \\
\text { gene }\end{array}$ & tetC & $\begin{array}{l}\text { GCTGTAGGCATAGGCTTGGT } \\
\text { GCCGGAAGCGAGAAGAATCA }\end{array}$ & 888 & Lanz et al., 2003 \\
\hline $\begin{array}{l}\text { Sulfonamide } \\
\text { gene }\end{array}$ & sull & $\begin{array}{l}\text { GTGACGGTGTTCGGCATTCT } \\
\text { TCCGAGAAGGTGATTGCGCT }\end{array}$ & 779 & Lanz et al., 2003 \\
\hline $\begin{array}{l}\text { Sulfonamide } \\
\text { gene }\end{array}$ & sul2 & $\begin{array}{l}\text { CGGCATCGTCAACATAACCT } \\
\text { TGTGCGGATGAAGTCAGCTC }\end{array}$ & 721 & Lanz et al., 2003 \\
\hline $\begin{array}{l}\text { Sulfonamide } \\
\text { gene }\end{array}$ & sul3 & $\begin{array}{l}\text { GAGCAAGATTTTTGGAATCG } \\
\text { CATCTGCAGCTAACCTAGGGCTTTGGA }\end{array}$ & 880 & $\begin{array}{l}\text { Perreten et al., } \\
2003\end{array}$ \\
\hline $\begin{array}{l}\text { Chloramphenicol } \\
\text { Resistance gene }\end{array}$ & $\mathrm{cmlA}$ & $\begin{array}{l}\text { CCGCCACGGTGTTGTTGTTATC } \\
\text { CACCTTGCCTGCCCATCATTAG }\end{array}$ & 699 & Van et al., 2008 \\
\hline $\begin{array}{l}\text { Chloramphenicol } \\
\text { Resistance gene }\end{array}$ & catAl & $\begin{array}{l}\text { AGTTGCTCAATGTACCTATAACC } \\
\text { TTGTAATTCATTAAGCATTCTGCC }\end{array}$ & 547 & Van et al., 2008 \\
\hline
\end{tabular}




\section{PFGE digestion}

In silico pulsed-field gel electrophoresis (PFGE) digestion and construction of the dendrogram was done in the website http://insilico.ehu.es/digest/. The enzyme used for the digestion was Sgr Dland recognition sequence was CG'TCGA_CG (San Millan et al., 2013; Bikandi et al., 2004).

\section{RESULTS AND DISCUSSION}

Fragments of different size were generated by $\operatorname{SgrDI}$ digestion and separated by pulsed-field gel electrophoresis (PFGE). Dendrogram was constructed in the website. Sixty-five Escherichia isolates were separated into 25 different groups at $50 \%$ similarity coefficient (Fig. 1).
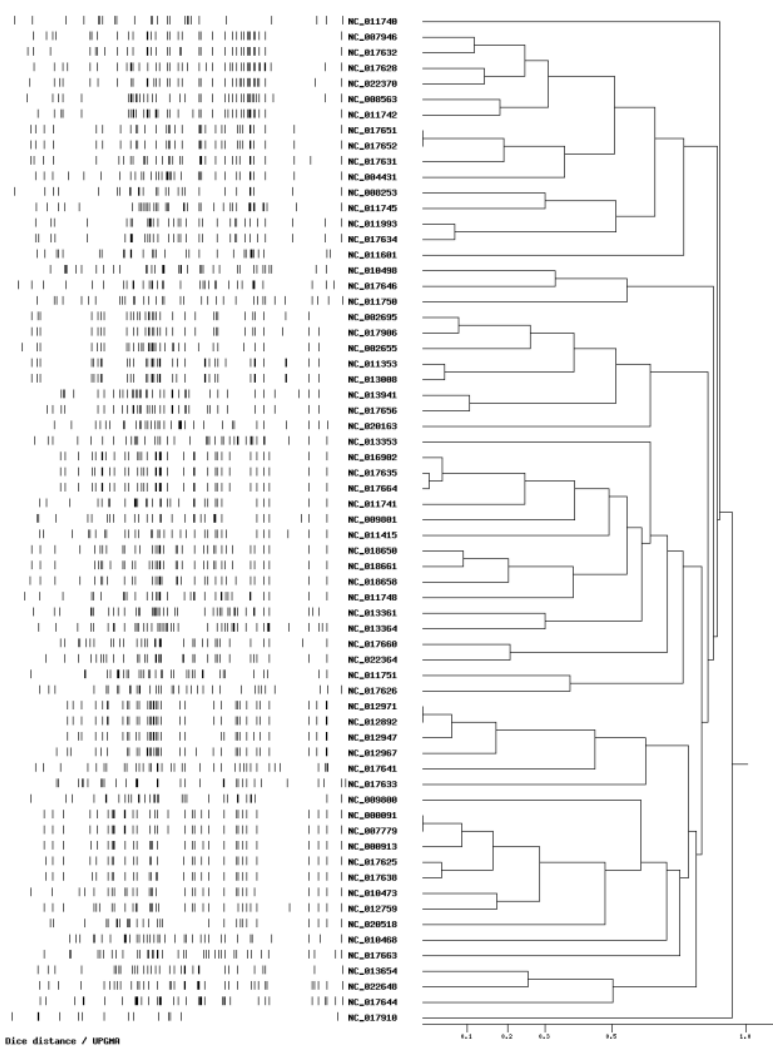

Fig. 1: Phylogenetic diversity of Escherichia coli identified by PFGE.

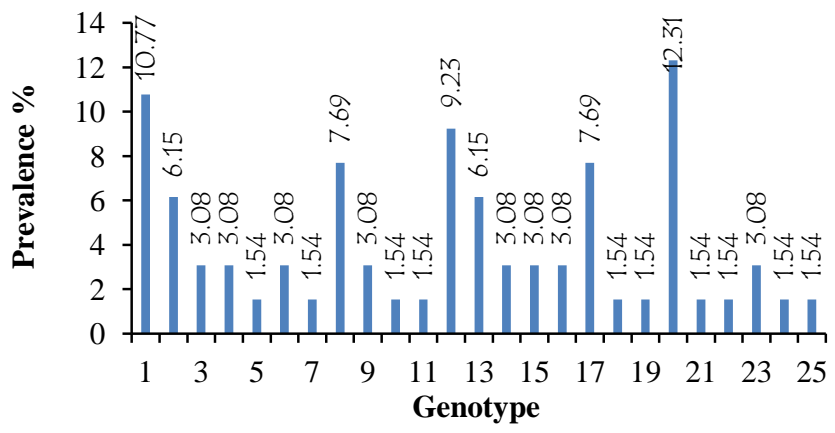

Fig. 2: Prevalence of genotypes.

Genotype 20 was more prevalent (12.31\%) followed by genotype $1(10.77 \%)$ and $12(9.23 \%)$. Genotype $5,7,10,11,18$,
19, 21, 22, 24 and 25 was present in low abundance containing $1.54 \%$ of the isolates (Fig. 2).

\section{Distribution of virulence genes within genotypes}

Lindenthal and Elsinghorst (2001) reported that watery diarrhea of $E$. coli strain was caused by heat labile (LT) or heat stable (ST) enterotoxin. Out of the 65 isolates tested for the LT1, STI, STII, VT1 and VT2 enterotoxins, three isolates (Escherichia coli E24377A, Escherichia coli ETEC H10407, Escherichia coli UMNK88) were found to possess LT1 enterotoxin and the gene product was $360 \mathrm{bp}$, and their percentage of prevalence was $4.62 \%$. The gene product for STI toxin was $160 \mathrm{bp}$ while that for STII toxin was 423bp. Isolates, Escherichia coli ETEC H10407 and Escherichia coli UMNK88, were positive for STI and STII enterotoxin, respectively; and prevalence of STI and STII enterotoxins were $1.54 \%$. These were Enterotoxigenic E. coli (ETEC) (Rajkhowa et al., 2009). Palaniappan et al. (2006) reported that ETEC causes traveler's and porcine and bovine diarrhea. Isolate Escherichia coli ETEC H10407 harboured both LT1 and STI enterotoxin and isolate Escherichia coli UMNK88 harboured both LT1 and STII enterotoxin. Verotoxin producing E.coli, responsible for foodborne disease in the USA, Canada, Japan and Europe, was reported by Griffin and Tauxe, 1991; Nataro and Kaper, 1998. The 130 bp gene product of $v t 1$ was found in 6 isolates, but no isolate harboured the $v t 2$ gene, these might be Enterohemorrhagic E. coli (EHEC). Genotypic distribution of this genes found that isolate NC_017633 Escherichia coli ETEC H10407 present in genotype 18 harboured both LT1 and STI enterotoxin (100\%) (Fig. 3). Low prevalence of LT1 enterotoxin was encountered in genotype 12 (16.67\%). The STII enterotoxin was present in genotype 17 and the prevalence was $20 \%$. Genotypic distribution of $v t 1$ gene found that isolateNC_013353 Escherichia coli O103:H2 str. 12009 present in genotype 11and NC_013361 Escherichia coli O26:H11 str. 11368 and NC_013364 Escherichia coli O111: H- str. 11128 present in genotype 14 harboured the $v t l$ gene. The $v t l$ gene was also present in genotype 8 but the prevalence was $60 \%$.

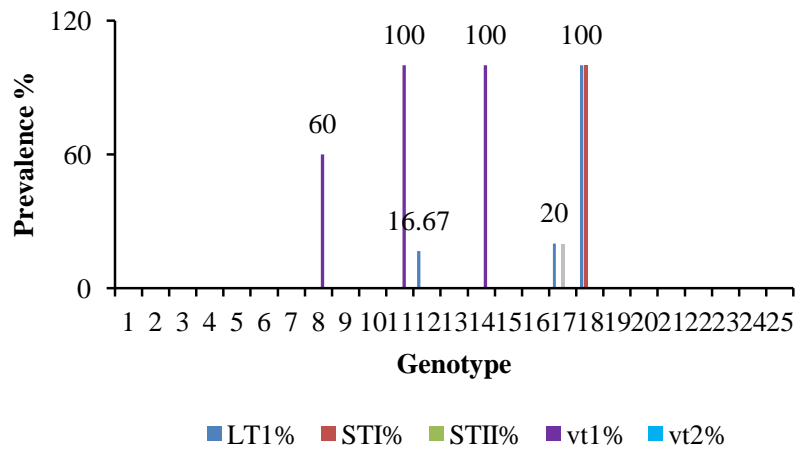

Fig. 3: Genotypic distribution of heat labile, heat stable and verotoxin genes.

Shiga toxin producing $E$ coli (STEC) produced two major toxins (Stx1 and Stx2) that causes hemorrhagic colitis (HC) and hemolytic uremic syndrome (HUS) (Karch et al., 2005; Karmali et al., 2010). The 302 bp gene, stxl was found in six 
isolates $(9.32 \%)$ while 516 bp gene, stx 2 was observed in 9 isolates $(13.85 \%)$. Four isolates had both $s t x 1$ and $s t x 2$ gene. Six isolates were identified to produce 302 bp gene product for stxl gene by in silico PCR amplification which was also found to be positive for $v t 1$ gene. Osek (2003) previously described that enteroaggregative heat stable enterotoxin 1, (astA) was responsible for porcine colibacillosis. Sarantuya et al. (2004) reported that two genes, astA and $\operatorname{agg} R$ gene, differentiate Enteroaggregative E. coli (EAEC) from other verotypes. The astA gene, encoding the toxin EAST1, produce $111 \mathrm{bp}$ gene product identified by in silico PCR amplification and the prevalence was $7.69 \%$. Out of five astA positive isolates, three of them were positive for both astA and lt 1 gene. So only isolate Escherichia coli 042 , Escherichia coli $\mathrm{P} 12 \mathrm{~b}$ were the representative of Enteroaggregative $E$ coli (EAEC). Gallegos et al. (1993) and Nataro et al. (1994) reported that aggR gene is the member of AraC/XylS family of bacterial transcriptional activators. Four isolates (their no.) were found to be positive for the aggR gene (6.15\%). Only Escherichia coli 042 contained both $a s t A$ and $a g g R$ gene. Enteroaggregative $E$. coli (EAEC) causes persistent diarrhea in humans (Palaniappan et $a l$. . 2006). Desmarchelier et al. (1998) described that $r f b E$ gene was used to detect $E$ coli 0157 . The $327 \mathrm{bp}$ gene product of the $r f b E$ gene was present in 5 isolates $(7.69 \%)$. These five isolates were also expressed eaeA gene. Figure 4 is representing the genotypic distribution of shiga toxin, enteroaggregative heat stable enterotoxin 1, $r f b E$ gene and $a g g R$ gene. Genotypic distribution shows that all the isolates present in genotype 11 harboured both stxl and stx2 genes (Fig. 4).

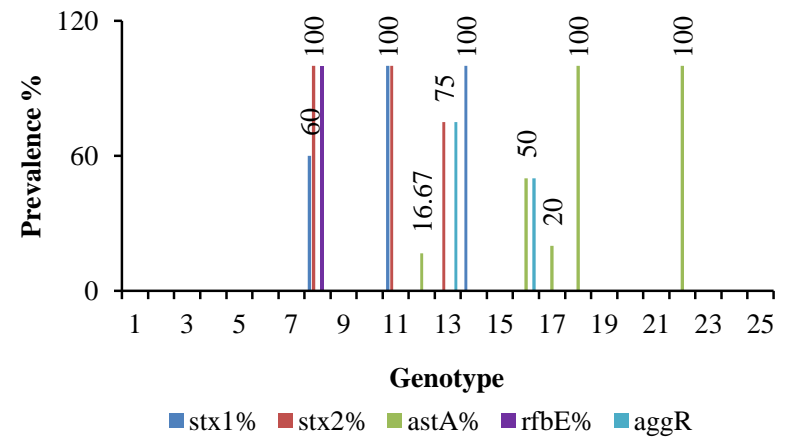

Fig. 4: Genotypic distribution of shiga toxin, $a s t A, r f b E$ and $a g g R$ genes.

The $s t x 1$ and stx 2 genes were also present in genotype 8 but their prevalence was $60 \%$ and $100 \%$, respectively. The stx 1 and stx 2 genes were also present in genotype $14(100 \%)$ and 13 (75\%). The astA gene was more abundant in genotype 18 and 22 (100\%). The astA gene was also present in genotype 12,16 and 17 and low prevalence was encountered in genotype 12 (16.67\%). All isolates present in genotype 8 contained $r f b E$ gene (100\%). Seventy five percent isolates present in genotype 13 harboured $a g g R$ gene. The $a g g R$ gene was also present in genotype 16 and fifty percent isolates present in genotype 16 harboured agg $R$ gene. Other important virulence factors include cytotoxic necrotizing factor (cnfl and cnf2), hemolysin ( $h l y A)$, the product of eaeA gene, intimin, and ipaH gene. Caprioli et al. (1983) reported that cnf gene was responsible for neonatal enteritis. The cytotoxic necrotizing factors, chfl was found in two isolates (Escherichia coli UM146 and Escherichia coli UTI89). No isolate was found to be positive for $c n f 2$. Ahmed et al. (2007) reported that cytotoxic necrotizing factor (CNF)is responsible for urinary tract infection. This is indicating that these were Uropathogenic E.coli (UPEC). The hlyA gene was found in 8 isolates. The prevalence of hlyA gene was $12.3 \%$. The $h l y A$ gene was present in both verotoxin and shiga toxin producing $E$ coli. So, these were representative of Enterohemorrhagic E coli (EHEC). Schmidt et al. (1995, 1996) reported that plasmid encoded enterohemolysin causes severe clinical disease in humans. The eaeA gene is more commonly associated with Enterohemorrhagic Escherichia coli (EHEC) and Enteropathogenic Escherichia coli (EPEC). Jerse et al. (1990) reported that eaeA gene is responsible for the attaching and effacing lesions in human enterocytes. Seven isolates had the eaeA gene and the percentage of prevalence was $10.77 \%$. Among the seven isolates, five was positive for both $e a e A$ and $r f b E$ as mentioned earlier. These five $e a e A$ positive isolates were also positive for the hlyA gene. It can be concluded that these five isolates were typical Enterohemorrhagic E. coli (EHEC) since they contained both hlyA and eaeA gene (Hegde et al., 2012). Two isolates had the eaeA gene only which means that these are Enteropathogenic E. coli (EPEC). Palaniappan et al. (2006) reported that EPEC is mainly responsible for diarrhea in children and animals. The $b f p A$ gene is also used for identification of Enteropathogenic $E$ coli (EPEC). No isolates harboured the $b f p A$ gene. Hegde et al. (2012) reported that E. coli harboured only $e a e A$ gene and no $b f p A$ gene are classified as atypical EPEC. So, these two isolates that harboured only eaeA genes were defined as atypical EPEC. Kaper et al. (2004) demonstrated that recent studies found more atypical EPEC strains. No invasion plasmid antigen, ipaH gene was found which is the common trait of Enteroinvasive E coli (EIEC). Palaniappan et al. (2006) also published that EIEC and EAEC genes were found only in humans. The cytotoxic necrotizing factor $c n f l$ was present in only genotype 1 and the prevalence was $28.57 \%$ (Fig. 5).

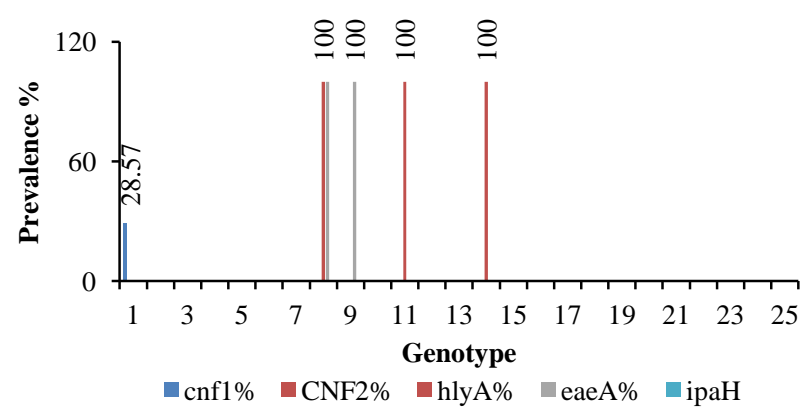

Fig. 5: Genotypic distribution of cytotoxic necrotizing factor, hemolysin, intimin gene.

Genotypic distribution of $h l y A$ gene showed that all isolates present in genotype 8,11 and genotype 14 harboured hlyA gene $(100 \%)$. All the isolates present in genotype 8 and 9 had the eaeA gene. 


\section{Distribution of antibiotic resistance gene within genotypes}

Olowe et al. (2013) reported that tetracycline resistance is acquired by energy dependent efflux pump system. Roberts (1996) reported that protein synthesis of tetracycline gene is inhibited by binding of aminoacyl-tRNA with the bacterial ribosome. The tetracycline resistance gene $\mathrm{A}$, tetA gene was present in 9 of the 65 isolates and hence the overall prevalence of this gene among the selected isolates was $13.85 \%$. The tet $B$ gene was seen in 6 isolates and hence the prevalence is $9.23 \%$. The tetC gene was present in only 2 isolates (Escherichia coli APEC O1, Escherichia coli $\mathrm{O} 83: \mathrm{H} 1$ str. NRG 857C) and the prevalence was $3.08 \%$. Genotypic distribution of tet $A$ and $t e t B$ gene was similar in genotype $13,14,16$ and 17 and their prevalence was $25 \%, 50 \%$, $50 \%$ and $20 \%$, respectively. The tetA gene was also present in genotype 4 and their prevalence in genotype 4 was $50 \%$. The tetC gene was present in genotype 1 and 12 and their prevalence was $14.29 \%$ and $16.67 \%$, respectively (Fig. 6).

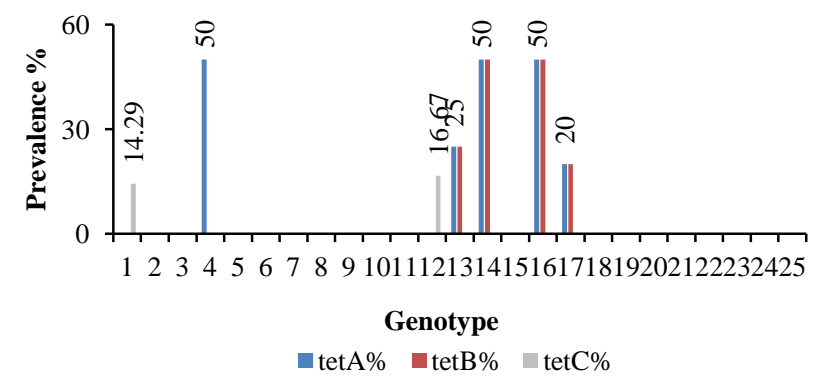

Fig. 6: Genotypic distribution of tetracycline resistance gene.

Ahmed et al. (2010) reported that chloramphenicol acetyptransferase, catAl gene is responsible for plasmid mediated resistance to chloramphenicol. Dorman and Foster (1982) demonstrated that chloramphenicol resistance is acquired by chloramphenicol acetyltransferase (CAT) enzymes that prevents the binding of chloramphenicol to 50S ribosome. Shaw (1984) also described that none of the catA genes has been shown to confer resistance to florfenicol and no homology was observed between CATs and Flo (florfenicol). Among the 65 isolates analyzed, six $(9.23 \%)$ isolates harboured a 547 bp amplicon for catAl gene. Bissonnette et al. (1991) reported that chloramphenicol resistance gene, $c m l A$ gene is also responsible for chloramphenicol resistance and confers resistance through non-enzymatic efflux pump. Bolton et al. (1999) reported that amino acid sequence of $\mathrm{cmlA}$ and flo is $50 \%$ similar but $\mathrm{cmlA}$ resistance to florfenicol is not clear. Only Escherichia coli UMNK88 was positive for the 699 bp PCR amplicon for $c m l A$ gene. Hence the prevalence was $1.54 \%$. The $s t r B$ gene was present in 9 isolates and produced 509 bp PCR product. So, the prevalence was $13.85 \%$. Genotypic distribution found that catAl gene was more prevalent in genotype $16(100 \%)$ (Fig. 7). Fifty percent of isolates present in genotype 4, 14 and 15 harboured catAl gene. Genotype 4 and 12 contained both $\operatorname{str} B$ and catAl gene. The $\mathrm{cmlA}$ gene was present in only genotype 17 .
Genotype 17 also harboured $s t r B$ gene. Prevalence of $\operatorname{str} B$ gene in genotype 4, 6 and 9 was 50\%. Perrenten and Boerlin (2003) and Skold (2001) reported that resistance to sulfonamide is acquired by sull, sul2 and sul3 gene (sulfonamine resistane genes). The sull gene was seen in 5 isolates and hence the prevalence was $7.69 \%$. The sul2 gene was present in 11 isolates and produced a $250 \mathrm{bp}$ PCR product. So, the prevalence was $16.92 \%$. None of the isolates were positive for sul3 gene. Figure 8 presented the genotypic distribution of sulfonamide genes. The sull gene was more prevalent in genotype 16 and low prevalence was encountered in genotype 1. All the isolates present in genotype 16 harboured sull gene. The prevalence of sul2 gene was more abundant in genotype 5. Genotypic distribution of sull and sul2 gene was similar in genotype 1, 4 and 17 and their prevalence was $14.29 \%, 50 \%$ and $20 \%$, respectively.

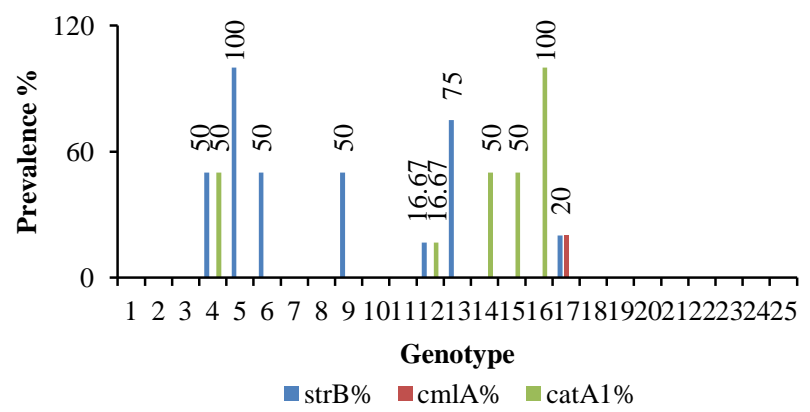

Fig. 7: Genotypic distribution of streptomycin and chloramphenicol resistance genes.

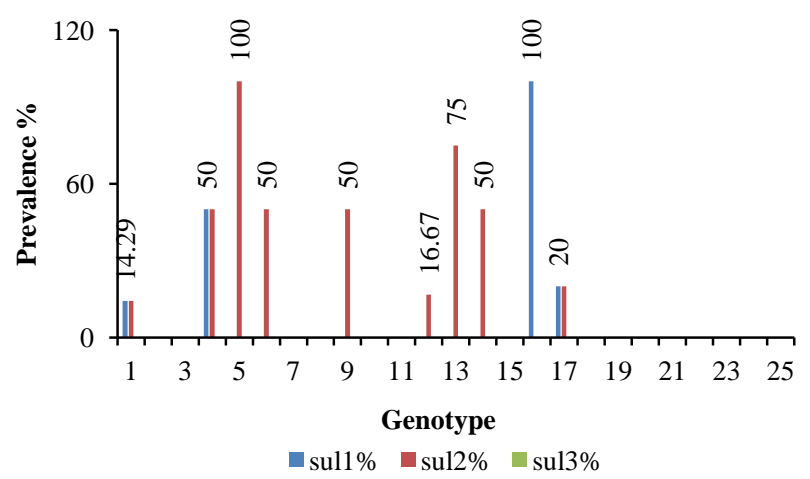

Fig. 8: Genotypic distribution of sulfonamide genes.

\section{Distribution of adhesin gene within genotypes}

The curlin subunit gene, $\operatorname{csg} A$ gene was seen in 31 of the isolates $(47.68 \%)$ with a $200 \mathrm{bp}$ gene product. The $\mathrm{crl}$ gene was present in 40 isolates $(61.54 \%)$. Hence a $250 \mathrm{bp}$ PCR product was seen. According to Hammar et al. (1996), genes that are involved in curli formation are encoded in $\operatorname{csg} B A$ operon and $\operatorname{csg} D E F G$ operon. Chapman et al. (2002) reported that without $\operatorname{csg} B$ gene no curli are assembled and unable to secrete $\operatorname{csg} A$ from the cell. Arnqyist et al. (1992) found that RpoS (RNA polymerase, sigma S) binds with $\operatorname{csg} B A$ promoter after interaction of $c r l$ with Rpo Sand therefore $\mathrm{crl}$ is required in most strains for curli expression. 
The curli regulatory gene, $\mathrm{crl}$ gene has a more regulatory role and $\operatorname{csg} A$ has a phenotypic role. Nine isolates had the $c r l$ gene but no $\operatorname{csg} A$ gene indicating that though has the gene for curli formation didn't exhibit phenotypic properties. All the isolates present in genotype $10,11,12,13,15,17,18,19,21$ and 22 harboured both $\operatorname{csg} A$ and $c r l$ genes (100\%) (Fig. 9). Genotype 14 and 20 also contained both $\operatorname{csg} A$ and $c r l$ genes. The prevalence of $\operatorname{csg} A$ and $c r l$ genes in genotype 14 were $50 \%$ and $100 \%$, respectively. The $\mathrm{crl}$ genes were also present in genotype 8, 9 (100\%) and lower abundance was seen in genotype 23 (50\%).

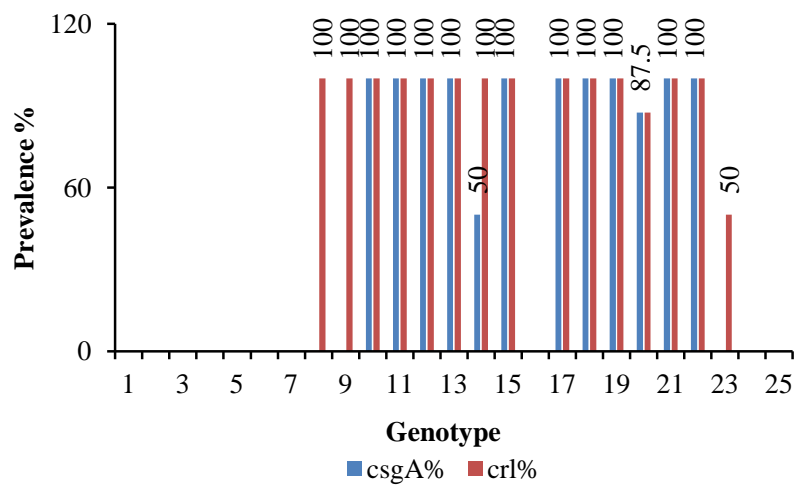

Fig. 9: Genotypic distribution of $\operatorname{csg} A$ and $c r l$ genes.

The S fimbrial adhesion, sfa gene was present in 5 isolates. The prevalence was $7.69 \%$. Isolates harbouring $s f a$ gene were also positive for two UPEC (uropathogenic Escherichia coli) strains, Escherichia coli UM146 and Escherichia coli UTI89. Morschhauser et al. (1990) reported that S fimbrial adhesion ( $s f a$ ) enable pathogenic Escherichia coli to bind to sialic acid containing eukaryotic receptor molecules. Previous study reported that (Stain et al., 1994) with the help of $s f a$ Sadhesin, S fimbriated-E coli bind to brain endothelial glycoproteins called NeuAc alpha 2,3galactose. This binding help the bacteria to penetrate blood brain barrier and develop meningitis. So, this $s f a$ containing isolates are more likely to cause sepsis and meningitis. Type 1 fimbriae are encoded by fim gene cluster (Iida et al., 2001). Mitra et al. (2013) described that it is an importance virulence factor in UTI (Urinary tract infection) infection. The fimA gene was present in 11 of the 65 isolates and hence the overall prevalence of this gene among the selected isolates was $16.92 \%$. As previously described by Blumer et al. (2005), this gene forms biofilm for cell surface attachment which enables them to persist in the harsh environment. Soto et al. (2007) reported that biofilm forming strains demonstrates higher type 1 fimbriae expression. None of the isolates had the pyelonephritis-associated pili $C$,papC gene. Uhlin et al. (1985) demonstrated that Pap pili are associated with pyelonephritis and is responsible for binding to digalactosidecontaining glycolipids on the uroepithelium. The type 1 fimbriae, fimA gene was more prevalent in genotype 17 (Fig. 10). Eighty percent isolates present in genotype 17 harboured fimA gene. The prevalence of fimA gene in genotype 20 was $62.5 \%$. The fimA gene had low abundance in genotype 14 and $16(50 \%)$ and rest of the genotypes harboured no fimA gene. The $s f a$ gene was present in only genotype $1(57.14 \%)$ and $3(50 \%)$.

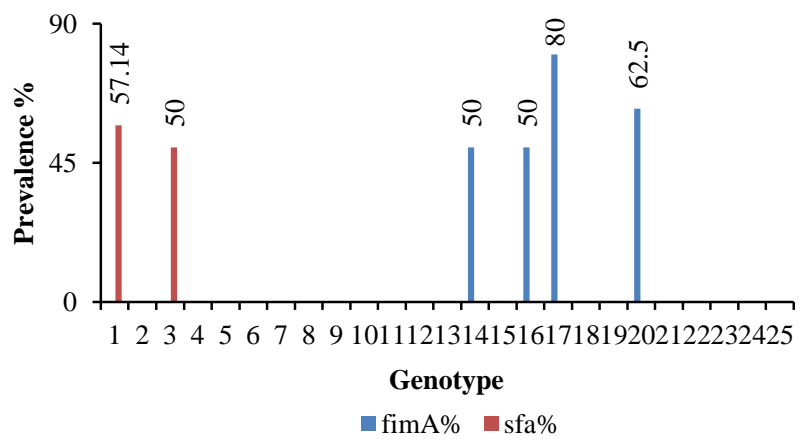

Fig. 10: Genotypic distribution of fimA and $s f a$ genes.

\section{CONCLUSION}

The most prevalent virulence factor was the shiga toxin producing gene, stx2 (13.85\%). Among the 65 isolates analyzed, the most prevalent verotype was EHEC (11 isolates) followed by ETEC ( 3 isolates). Five isolates were classified as typical EHEC since they harboured both $h l y A$ and $e a e A$ gene and two isolates were classified as atypical EPEC since they carried only eaeA gene. Genotypic distribution showed that genotype 8 was the most virulent where it harbours 6 virulent genes that defined in EHEC. This study showed that the most prevalent antibiotic resistance gene was sulfonamide resistance gene, sul2 (16.92\%). Genotype 17 contained all antibiotic resistance genes, except tetC, sul3 and catAl gene. Genotype 4 contained 5 antibiotic resistance genes. The $\mathrm{crl}$ gene was the most prevalent adhesive gene. Genotype 17 contained three adhesive genes. Adequate hygiene practice should be implemented strictly to control $E$ coli contaminations. Adequate heat and temperature should also be maintained for the production of dairy products.

\section{Financial support and sponsorship: None.}

Conflict of Interests: There are no conflicts of interest.

\section{REFERENCES}

Ahmed MO, Clegg PD, Williams NJ, Baptiste KE, Bennett M. Antimicrobial resistance in equine faecal Escherichia coli isolates from North West England. Ann Clin Microbiol Antimicrob, 2010; 9(1):12

Ahmed W, Tucker J, Bettelheim KA, Neller R, Katouli M. Detection of virulence genes in Escherichia coli of an existing metabolic fingerprint database to predict the sources of pathogenic E. coli in surface waters. Water res, 2007; 41(16):3785-3791.

Aldick T, Bielaszewska M, Zhang W, Brockmeyer J, Schmidt $\mathrm{H}$, Friedrich AW, Karch $\mathrm{H}$. Hemolysin from Shiga toxin-negative Escherichia coli $\mathrm{O} 26$ strains injures microvascular endothelium. Microbes Infect, 2007; 9(3):282-290.

Anonymous. 2004. Canadian Integrated Program for Antimicrobial Resistance Surveillance (CIPARS) 2002. Health Canada, Ottawa, Canada. 
Antao EM, Wieler LH, Ewers C. Adhesive threads of extraintestinal pathogenic Escherichia coli. Gut Pathog, 2009; 1:22.

Arnqvist A, Olsen A, Pfeifer J, Russell DG, Normark S. The Crl protein activates cryptic genes for curli formation and fibronectin binding in Escherichia coli HB101. Mol. Microbiol, 1992; 6: 2443-52.

Bikandi J, San Millán R, Rementeria A, Garaizar J.In silico analysis of complete bacterial genomes: PCR, AFLP-PCR and endonuclease restriction. Bioinformatics, 2004; 20(5):798-799.

Bissonnette L, Champetier S, Buisson JP, Roy PH. Characterization of the nonenzymatic chloramphenicol resistance $(\mathrm{cmlA})$ gene of the In4 integron of Tn1696: similarity of the product to transmembrane transport proteins. J Bacteriol, 1991; 173:4493-4502.

Blanco M, Blanco JE, Mora A, Dahbi G, Alonso MP, Gonza' lez EA, Berna'rdez MI,Blanco J. Serotypes, virulence genes, and intimin types of Shiga toxin (verotoxin)-producing Escherichia coli isolates from cattle in Spain and identification of a new intimin variant gene (eae-j). J Clin Microbiol, 2004; 42:645-651.

Blumer C, Kleefeld A, Lehnen D, Heintz M, Dobrindt U, Nagy G, Wendisch VF. Regulation of type 1 fimbriae synthesis and biofilm formation by the transcriptional regulator LrhA of Escherichia coli. Microbiology, 2005; 151(10):3287-3298.

Bolton LF, Kelley LC, Lee MD, Fedorka-Cray PJ, Maurer JJ. Detection of multidrug-resistant Salmonella enterica serotype typhimurium DT104 based on a gene which confers cross-resistance to florfenicol and chloramphenicol. J Clin Microbiol, 1999; 37:1348-1351.

Brzuszkiewicz E, Thurmer A, Schuldes J, Leimbach A, Liesegang H, Meyer F-D, Boelter J, Petersen H, Gottschalk G, Daniel R. Genome sequence analyses of two isolates from the recent Escherichia coli outbreak in Germany reveal the emergence of a new pathotype: Entero-Aggregative-Haemorrhagic Escherichia coli (EAHEC). Arch Microbiol, 2011;193:883-891.

Caprioli A, Falbo V, Roda LG, Ruggeri FM, Zona C. Partial purification and characterization of an Escherichia coli toxic factor that induces morphological cell alterations. Infect Immun, 1983; 39(3):13001306.

Chapman MR, Robinson LS, Pinkner JS, Roth R, Heuser J, Hammar M, Normark S, Hultgren SJ. Role of Escherichia coli curli operons in directing amyloid fiber formation. Science,2002; 295:851-5.

Croxen MA, Finlay BB. Molecular mechanisms of Escherichia coli pathogenicity. Nat Rev Microbiol, 2010; 8(1):26-38.

Danmap Danmap 2003: Use of antimicrobial agents and occurrence of antimicrobial resistance in bacteria from food animals, foods and humans in Denmark. Danish Zoonoses Center, Sørborg, Denmark, 2004.

Desmarchelier PM, Bilge SS, Fegan N, Mills L, Vary JC, Tarr PI. A PCR specific for Escherichia coli $\mathrm{O} 157$ based on the rfb locus encoding O157 lipopolysaccharide. J Clin Microbiol, 1998; 36(6):18011804.

Dorman CJ, Foster TJ. Nonenzymatic chloramphenicol resistance determinants specified by plasmids R26 and R55-1 in Escherichia coli $\mathrm{K}-12$ do not confer high-level resistance to fluorinated analogs. Antimicrob Agents Chemother, 1982; 22:912-914.

Gallegos MT, Michan C, Ramos JL. The XylS/AraC family of regulators. Nucleic Acids Res, 1993; 21:807-810

Griffin PM, Tauxe RV. The epidemiology of infections caused by Escherichia coli $\mathrm{O} 157: \mathrm{H} 7$, other enterohemorrhagic E. coli, and the associated hemolytic uremic syndrome. Epidemiol Rev, 1991; 13:60-98.

Guerra B, Junker E, Schroeter A, Malorny B, Lehman S, Helmuth R. Phenotypic and genotypic characterization of antimicrobial resistance in German Escherichia coli isolates from cattle, swine, and poultry. J Antimicrob Chemother, 2003; 52:489-492.

Hammar M, Bian Z, Normark S. Nucleator-dependent intercellular assembly of adhesive curli organelles in Escherichia coli. Proc Natl Acad Sci USA, 1996; 93:6562-6.

$\mathrm{He}$ H, Cooper JN, Mishra A, Raskin DM. Stringent response regulation of biofilm formation in Vibrio cholerae. J. Bacteriol, 2012; 194(11):2962-2972.
Hegde A, Ballal M, Shenoy S. Detection of diarrheagenic Escherichia coli by multiplex PCR. Indian J Med Microbiol, 2012; 30(3):279.

Hughs JM, Murad F, Chang B, Guerrant RL. Role of cyclic GMP in the action of heat-stable enterotoxin of Escherichia coli. Nature, 1978; 271:755-756.

Iida KI, Mizunoe Y, Wai SN, Yoshida SI. Type 1 fimbriation and its phase switching in diarrheagenic Escherichia coli strains. Clin Diagn Lab Immunol, 2001; 8:489-495

Jafari A, Aslani MM, Bouzari S. Escherichia coli: A brief review of diarrheagenic pathotypes and their role in diarrheal diseases in Iran. Iran J Microbiol, 2012;4:102-117.

Jerse AE, Yu J, Tall BD, Kaper JP. A genetic locus of enteropathogenic Escherichia coli necessary for the production of attaching anf effacing lesions on tissue culture cells. Proc Natl Acad Sci USA, 1990; 87(20):7830-7843.

Johnson JR, Stell AL. Extended virulence genotypes of Escherichia coli strains from patients with urosepsis in relation to phylogeny and host compromise. J Infect Dis, 2000; 181:261-272.

Johnson TJ, Nolan LK. Pathogenomics of the Virulence Plasmids of Escherichia coli. Microbiol Mol Biol Rev, 2009; 4:750-774.

Kaper JB, Nataro JP, Mobley HL. Pathogenic Escherichia coli. Nat Rev Microbiol, 2004; 2:123-40.

Karch H, Tarr PI, Bielaszewska M. Enterohaemorrhagic Escherichia coli in human medicine. IntJ Med Microbiol, 2005; 295:405418.

Karmali MA, Gannon V, Sargeant JM. Verocytotoxinproducing Escherichia coli (VTEC). Vet Microbiol, 2010; 140:360-370.

Lanz R, Kuhnert P, Boerlin P. Antimicrobial resistance and resistance gene determinants in clinical Escherichia coli from different animal species in Switzerland. Vet Microbiol, 2003; 91:73-84.

Le Bouguenec C, Archambaud M, Labigne A. Rapid and specific detection of the pap, afa, and sfa adhesin-encoding operons in uropathogenic Escherichia coli strains by polymerase chain reaction. J Clin Microbiol, 1992; 30(5):1189-1193.

Lindenthal C, Elsinghorst EA. Enterotoxigenic Escherichia coli TibA glycoprotein adheres to human intestine epithelial cells. Infect Immun, 2001; 69(1):52-57.

López-Banda DA, Carrillo-Casas EM, Leyva-Leyva M, Orozco-Hoyuela G, Manjarrez-Hernández ÁH, Arroyo-Escalante S, Hernández-Castro R. Identification of virulence factors genes in Escherichia coli isolates from women with urinary tract infection in Mexico. Bio Med Res Int, 2014.

Luscher D, Altwegg M. Detection of Shigella, enteroinvasive and enterotoxigenic Escherichia coli using the polymerase chain reaction (PCR) in patients returning from tropical countries. Mol Cell Probes, 1994;8:285-290.

Madsen L, Aarestrup FM, Olsen JE. Characterization of streptomycin resistance determinants in Danish isolates of Salmonella typhimurium. Vet Microbiol, 2000; 75:73-82.

Maurer JJ, Brown TP, Steffens WL, Thayer SG. The occurrence of ambient temperature-regulated adhesions, curli, and the temperaturesensitive hemagglutinin Tsh among avian Escherichia coli. Avian Dis, 1998; 42:106-118.

Mitra A, Palaniyandi S, Herren CD, Zhu X, Mukhopadhyay S. Pleiotropic roles of $u v r Y$ on biofilm formation, motility and virulence in uropathogenic Escherichia coli CFT073. PLoS One, 2013; 8:e55492.

Moon HW. Mechanisms in the pathogenesis of diarrhea: A review. J Am Vet Med Assoc,1978; 172:443-448.

Morschhäuser J, Hoschützky H, Jann K, Hacker J. Functional analysis of the sialic acid-binding adhesion SfaS of pathogenic Escherichia coli by site-specific mutagenesis. Infect Immun, 1990;58(7):2133-8.

Mulvey MA. Adhesion and entry of uropathogenic Escherichia coli. Cell Microbiol, 2002; 4:257-271

Mulvey MA, Lopez-Boado YS, Wilson CL, Roth R, Parks WC, Heuser J, Hultgren SJ. Induction and evasion of host defenses by type 1- 
piliated uropathogenic Escherichia coli. Science, 1998; 282(5393):14941497.

Nataro JP, Kaper JB. Diarrheagenic Escherichia coli. Clin Microbiol Rev, 1998; 11:142-201.

Nataro JP, Yikang D, Yingkang D, Walker K. AggR, a transcriptional activator of aggregative adherence fimbria I expression in enteroaggregative Escherichia coli. J Bacteriol, 1994; 176:4691-4699

Nowrouzian F, Adlerberth I, Wold AE. P fimbriae, capsule and aerobactin characterize colonic resident Escherichia coli. Epidemiol Infect, 2001; 126(01):11-18.

Olowe OA, Idris OJ, Taiwo SS. Prevalence of tet genes mediating tetracycline resistance in Escherichia coli clinical isolates in Osun State, Nigeria. Eur J Microbiol Immunol, 2013; 3(2):135-140.

Osek J. Detection of the enteroaggregative Escherichia coli heat-stable enterotoxin 1 (EAST1) gene and its relationship with fimbrial and enterotoxin markers in $E$. coli isolates from pigs with diarrhoea. Vet Microbiol, 2003; 91(1):65-72.

Palaniappan RU, Zhang Y, Chiu D, Torres A, DebRoy C, Whittam TS, Chang YF. Differentiation of Escherichia coli pathotypes by oligonucleotide spotted array. J Clin Microbiol, 2006; 44(4):1495-1501.

Pass MA, Odedra R, Batt RM. Multiplex PCRs for identification of Escherichia coli virulence genes. J Clin Microbiol, 2000; 38(5):2001-2004.

Perreten V, Boerlin P. A new sulfonamide resistance gene (sul3) in Escherichia coli is widely spread in the pig population of Switzerland. Antimicrob Agents Chemother, 2003; 47:1169-1172.

Pollard DR, Johnson WM, Lior H, Tyler SD, Rozee KR. Rapid and specific detection of verotoxin genes in Escherichia coli by the polymerase chain reaction. J Clin Microbiol, 1990; 28:540-5.

Rajkhowa S, Hussain I, Rajkhowa C. Detection of heat-stable and heat-labile enterotoxin genes of Escherichia coli in diarrhoeicfaecal samples of mithun (Bos frontalis) calves by polymerase chain reaction. $\mathrm{J}$ Appl Microbiol, 2009; 106(2):455-458.

Ratchtrachenchai OA, Subpasu S, Ito K.Investigation on enteroaggregative Escherichia coli infection by multiplex PCR. BullDep Med Sci, 1997; 39:211-220

Roberts MC. Tetracycline resistance determinants: mechanisms of action, regulation of expression, genetic mobility, and distribution. FEMS Microbiol Rev, 1996; 19:1-24.

San Millán RM, Martínez-Ballesteros I, Rementeria A, Garaizar J, Bikandi J. Online exercise for the design and simulation of PCR and PCR-RFLP experiments. BMC Res Notes, 2013; 6(1):513.

Sarantuya J, Nishi J, Wakimoto N, Erdene S, Nataro JP, Sheikh J, Miyata K. Typical enteroaggregative Escherichia coli is the most prevalent pathotype among $E$. coli strains causing diarrhea in Mongolian children. J Clin Microbiol, 2004; 42(1):133-139.

Schmidt H, Beutin L, Karch H. Molecular analysis of the plasmid-encoded hemolysin of Escherichia coli O157:H7 strain EDL 933. Infect Immun, 1995; 63:1055-1061.

Schmidt H, Karch H. Enterohemolytic phenotypes and genotypes of Shiga-toxin-producing Escherichia coli O111 strains from patients with diarrhea and hemolytic-uremic syndrome. J Clin Microbiol, 1996; 34:2364-2367.

Shaw WV. Bacterial resistance to chloramphenicol. Br Med Bull, 1984;40:36-41.

Skold O. Resistance to trimethoprim and sulfonamides. Vet Res, 2001; 32:261-273
Sohel I, Puente JL, Murray WJ, Vuopio-Varkila J, Schoolnik GK. Cloning and characterization of the bundle-forming pilin gene of enteropathogenic Escherichia coli and its distribution in Salmonella species. Mol Microbiol, 1993; 7:563-575.

Soto SM, Smithson A, Martinez JA, Horcajada JP, Mensa J, Vila J. Biofilm formation in uropathogenic Escherichia coli strains: relationship with prostatitis, urovirulence factors and antimicrobial resistance. J Uro, 2007; 177(1):365-368.

Stins MF, Prasadarao NV, Ibric L, Wass CA, Luckett P, Kim KS. Binding characteristics of S fimbriated Escherichia coli to isolated brain microvascular endothelial cells. Am J Pathol, 1994; 145(5):1228.

Uhlin BE, Norgren M, Båga M, Normark S. Adhesion to human cells by Escherichia coli lacking the major subunit of a digalactosidespecific pilus-adhesin. Proc Nat Aca Sci USA, 1985;82(6):1800-1804.

Van TT, Chin J, Chapman T, Tran LT, Coloe PJ. Safety of raw meat and shellfish in Vietnam: an analysis of Escherichia coli isolations for antibiotic resistance and virulence genes. Int J Food Microbiol, 2008; 124:217-223.

Vila J, Gene A, Vargas M, Gascon J, Latorre C, De Anta MJ. A case-control study of diarrhoea in children caused by Escherichia coli producing heat-stable enterotoxin (EAST-1). J Med Microbiol, 1998; 47(10):889-891.

Wang G, Clark CG, Rodgers FG. Detection in Escherichia coli of the genes encoding the major virulence factors, the genes defining the O157: H7 serotype, and components of the type 2 Shiga toxin family by multiplex PCR. J Clin Microbiol, 2002; 40(10):3613-3619.

Wu CJ, Hsueh PR, Ko WC. A new health threat in Europe: Shiga toxin producing Escherichia coli O104:H4 infections. J Microbiol Immunol Infect, 2011;44:390-393.

Yamamoto T. Nakazawa, M. Detection and sequences of the enteroaggregative Escherichia coli heat-stable enterotoxin 1 gene in enterotoxigenic $E$. coli strains isolated from piglets and calves with diarrhea. J Clin Microbiol, 1997; 35:223-227

\section{How to cite this article:}

Nahar N, Naz S, Asad S, Islam MS, Al Aman DA, Setu NI, Ahmed T, Islam MK, Rahman MM, Bari MA, Rashid RB. In silico Pulsed Field Gel Electrophoresis and Molecular characterization of Escherichia coli. J App Pharm Sci, 2017; 7 (11): 159-167. 